\title{
Social STRATIfication AND
}

MOBILITY IN CENTRAL VERACRUZ 


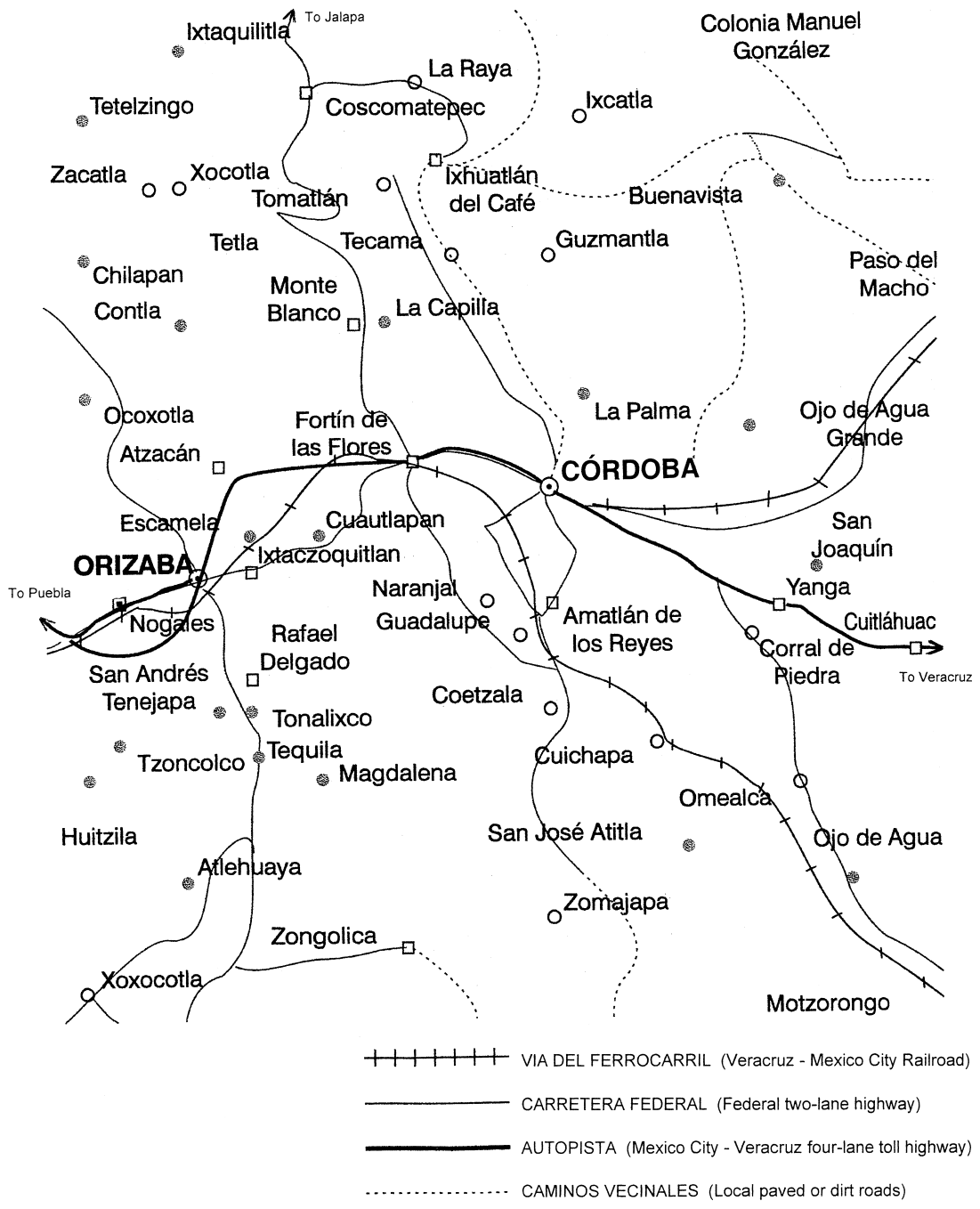




\section{Hugo G. SOcial STRATIfication Nutini AND MOBILITY IN GENTRAL VERACRUZ}

$\checkmark \begin{aligned} & \text { Univin } \\ & \text { Austiti }\end{aligned}$ 
Copyright (C) 2005 by the University of Texas Press

All rights reserved

Printed in the United States of America

First edition, 2005

Requests for permission to reproduce material from this work should be sent to Permissions, University of Texas Press, Box 7819, Austin, TX 78713-7819.

www.utexas.edu/utpress/about/bpermission.html

(2) The paper used in this book meets the minimum requirements of ANSI/NISO Z39.48-1992 (R1997)

(Permanence of Paper).

Library of Congress Cataloging-in-Publication Data

Nutini, Hugo G.

Social stratification and mobility in central Veracruz /

Hugo G. Nutini._- 1st ed.

p. $\mathrm{cm}$.

Includes bibliographical references (p. ) and index.

ISBN 0-292-70695-2 (cloth : alk. paper)

1. Social stratification-Mexico-Córdoba Region

(Veracruz-Llave) 2. Social mobility-Mexico-

Córdoba Region (Veracruz-Llave) 3. Córdoba Region

(Veracruz-Llave, Mexico)-Social conditions -

2oth century. I. Title.

HN120.C67N87 2005

$305 \cdot 5^{\prime} 12^{\prime} 072-\mathrm{dc} 22$ 